\title{
Inactivation of $\operatorname{lm} p A$, Encoding a LIMPII-related Endosomal Protein, Suppresses the Internalization and Endosomal Trafficking Defects in Profilin-null Mutants
}

\author{
Lesly Temesvari, ${ }^{*+}$ Linyi Zhang, ${ }^{\ddagger}$ Brent Fodera, ${ }^{*}$ Klaus-Peter Janssen, $\$$ \\ Michael Schleicher, $\$$ and James A. Cardelli*\|
}

*Feist-Weiller Cancer Center and ₹Department of Microbiology and Immunology, Louisiana State
University Medical Center, Shreveport, Louisiana 71130; and \$A.-Butenandt-Institut fuer Zellbiologie,
Ludwig-Maximilians-Universtaet, 80336 Muenchen, Germany

Submitted October 1, 1999; Revised March 14, 2000; Accepted March 28, 2000

Monitoring Editor: David Drubin

\begin{abstract}
Profilin is a key phosphoinositide and actin-binding protein connecting and coordinating changes in signal transduction pathways with alterations in the actin cytoskeleton. Using biochemical assays and microscopic approaches, we demonstrate that profilin-null cells are defective in macropinocytosis, fluid phase efflux, and secretion of lysosomal enzymes but are unexpectedly more efficient in phagocytosis than wild-type cells. Disruption of the $\operatorname{lmp} A$ gene encoding a protein (DdLIMP) belonging to the CD36/LIMPII family suppressed, to different degrees, most of the profilin-minus defects, including the increase in F-actin, but did not rescue the secretion defect. Immunofluorescence microscopy indicated that DdLIMP, which is also capable of binding phosphoinositides, was associated with macropinosomes but was not detected in the plasma membrane. Also, inactivation of the $\operatorname{lmp} A$ gene in wild-type strains resulted in defects in macropinocytosis and fluid phase efflux but not in phagocytosis. These results suggest an important role for profilin in regulating the internalization of fluid and particles and the movement of material along the endosomal pathway; they also demonstrate a functional interaction between profilin and DdLIMP that may connect phosphoinositide-based signaling through the actin cytoskeleton with endolysosomal membrane trafficking events.
\end{abstract}

\section{INTRODUCTION}

Profilins, ubiquitous actin-binding proteins, were originally thought to act primarily as key negative regulators of actin polymerization by sequestering globular $(G)$-actin monomers and preventing their incorporation into filamentous (F)-actin (Carlsson et al., 1977). In addition to sequestration of actin monomers, however, recent observations suggest that profilins may also have other diverse functions in the cell. For example, upon binding to actin monomers, profilin can act as a nucleotide exchange factor, charging G-actin with ATP, and can promote actin polymerization (Mockrin and Korn, 1980; Goldschmidt-

\footnotetext{
${ }^{+}$Present address: Department of Biological Sciences, Clemson University, Clemson, SC 29632.

" Corresponding author. E-mail address: jcarde@1sumc.edu. Abbreviations used: F-actin, filamentous actin; G-actin, globular actin; PI, phosphoinositide(s); $\mathrm{PIP}_{2}$, phosphoinositide bisphosphate; PLC, phospholipase C.
}

Clermont et al., 1992; Pantaloni and Carlier, 1993; Vinson et al., 1998). Moreover, profilin can (i) bind phosphoinositides (PI), especially phosphoinositide bisphosphate $\left(\mathrm{PIP}_{2}\right)$, with high affinity (Goldschmidt-Clermont et al., 1990; Sohn et al., 1995; Lambrechts et al., 1997), (ii) bind to and activate PI 3-kinases (Singh et al., 1996; Bhargavi et al., 1998), and (iii) inhibit some forms of phospholipase C- $\gamma$ (PLC- $\gamma$ ) (Goldschmidt-Clermont et al., 1990; Lambrechts et al., 1997). These latter observations suggest that profilin may also play a role in PI 3-kinase- and PLC-dependent signal transduction pathways and link these pathways to changes in the actin cytoskeleton. In addition, profilin has recently been shown to form complexes with proteins such as dynamin I, clathrin, synapsin, a member of the NSF/sec18 family of proteins, Rho-associated coiled-coil kinase, and the Rac-associated protein NAP1 (Witke et al., 1998). The components of these complexes are involved in endocytosis, vesicle trafficking, and Rho GTPase-dependent signaling, suggesting that profilin may also function in these cellular events. 
To further explore the potential role of profilin in membrane trafficking, we have used the genetically tractable eukaryote Dictyostelium discoideum, an organism that has proven to be a useful system in which to investigate the molecular mechanisms governing protein and vesicle trafficking along both the secretory and endocytic pathways. A number of key endosomal, phagosomal, and secretory pathway regulatory proteins have been identified in $D$. discoideum, including clathrin (Ruscetti et al., 1994), myosin I's (Temesvari et al., 1996b), coronin (Maniak et al., 1995; Rauchenberger et al., 1997), the small GTPases Rab7 (Buczynski et al., 1997a) and RabD (Bush et al., 1996), actin (Temesvari et al., 1996c), PI 3-kinases (Buczynski et al., 1997b), the small GTPases RacC (Seastone et al., 1998) and Rap1 (Seastone et al., 1999), and vacuolin B (Rauchenberger et al., 1997; Jenne et al., 1998).

In $D$. discoideum, two profilin isoforms have been identified, and mutants $\left(p I / I I^{-}\right)$lacking both of these proteins exhibit a severe combined phenotype that includes defects in development, motility, cytokinesis, and regulation of Factin polymerization (Haugwitz et al., 1994). The absence of profilin results in a twofold increase in the F-actin/G-actin ratio, suggesting that in Dictyostelium profilin acts as a negative regulator of F-actin polymerization (Haugwitz et al., 1994).

Interestingly, genetic disruption of $\operatorname{lmp} A$, a gene encoding an integral membrane protein, DdLIMP, with homology to lysosomal membrane proteins of the mammalian CD36/ LIMPII family of proteins, partially suppresses the profilinnull developmental defect (Karakesisoglou et al., 1999). These data suggest a functional connection between profilin and lysosome-associated proteins, consistent with the idea that profilin may play a role in membrane trafficking. The function of DdLIMP is not known; however, like profilin, it can bind $\mathrm{PIP}_{2}$ with high affinity and is localized to vesicular structures of putative endosomal origin (Karakesisoglou et al., 1999). This initial analysis suggested a role for DdLIMP in vesicle transport. To further our understanding of the roles played by profilin and DdLIMP, we have examined several endocytic and exocytic processes in five different $D$. discoideum cell lines: (i) a cell line in which both profilin genes have been disrupted $\left(p I / I I^{-}\right)$; (ii) two mutant cell lines in which $\operatorname{lmp} A$ was disrupted in the profilin-null background by homologous recombination (T1.5) or by restriction endonuclease-mediated integration ( $\mathrm{Rb} 2)$; (iii) a mutant null for the $\operatorname{lmp} A$ gene; and (iv) a wild-type parental cell line (Ax2). Here we present evidence demonstrating that profilin is a negative regulator of phagocytosis but a positive regulator of macropinocytosis and transport of fluid phase along the endosomal pathway; we also demonstrate that DdLIMP may functionally interact with a profilin-regulated pathway to coordinate these various processes.

\section{MATERIALS AND METHODS}

\section{Strains and Culture Conditions}

The generation of the stable $D$. discoideum profilin double null mutant cell line $\left(p I / I I^{-}\right)$, the single mutant $\operatorname{lmp} A^{-}$, and the profilin/ DdLIMP triple null mutant cell lines ( $\mathrm{Rb} 2$ and $\mathrm{T} 1.5)$ is described elsewhere (Haugwitz et al., 1994; Karakesisoglou et al., 1999). The parental strain, Ax2, was grown in tissue culture flasks in HL5 medium ( $1 \%$ oxoid proteose peptone, $1 \%$ glucose, $0.5 \%$ yeast extract
[Difco Laboratories, Detroit, MI[, $2.4 \mathrm{mM} \mathrm{Na} \mathrm{HPO}_{4}, 8.8 \mathrm{mM}$ $\mathrm{KH}_{2} \mathrm{PO}_{4}, \mathrm{pH}$ 6.5) at room temperature. The $\mathrm{pI} / \mathrm{II}^{-}$cell line was maintained in HL5 medium supplemented with $10 \mu \mathrm{g} / \mathrm{ml} \mathrm{G418}$ (Sigma Chemical, St. Louis, MO), whereas the Rb2 and T1.5 cell lines were maintained in HL5 medium supplemented with both G418 (10 $\mu \mathrm{g} / \mathrm{ml})$ and blastocidin $(10 \mu \mathrm{g} / \mathrm{ml})$. All assays described below were performed with cells in the log phase of growth.

\section{Measurement of Fluid Phase Traffic}

Total fluid phase endocytosis (micropinocytosis and macropinocytosis) and exocytosis were measured according to the methods of Temesvari et al. (1996b). Log-phase cells were shaken from tissue culture flasks, harvested by centrifugation $(500 \times g, 5 \mathrm{~min})$, and resuspended at a concentration of $3 \times 10^{6}$ cells $/ \mathrm{ml}$ in fresh HL5 medium supplemented with $2 \mathrm{mg} / \mathrm{ml}$ FITC-dextran $\left(M_{\mathrm{r}} 70,000\right.$; Sigma Chemical). Resuspended cells were shaken at $120 \mathrm{rpm}$, and endocytosis was allowed to proceed at room temperature for $3 \mathrm{~h}$, after which the cells were harvested, washed twice with cold HL5 medium, and finally resuspended in fresh HL5 medium to allow release of the fluid phase marker (exocytosis). Exocytosis of FITCdextran was allowed to proceed at room temperature for $2 \mathrm{~h}$.

At the times indicated during endocytosis or exocytosis (see RESULTS), 1-ml samples $\left(3 \times 10^{6}\right.$ cells) were harvested by centrifugation, washed twice with cold HL5 medium and once with cold wash buffer (5 mM glycine, $100 \mathrm{mM}$ sucrose, $\mathrm{pH} 8.5$ ), and then stored on ice before fluorescence measurements. The cells were lysed by the addition of $0.1 \mathrm{ml}$ of $10 \%$ (vol/vol) Triton X-100 to the pellets and diluted $20 \times$ in wash buffer for fluorescence and protein measurements. Total cellular protein from detergent-lysed amebae was measured with the use of the bicinchoninic acid protein assay system (Pierce, Rockford, IL) according to the manufacturer's protocol. Cell-associated fluorescence was measured on a Hitachi (Tokyo, Japan; model F-4010) fluorimeter with excitation and emission wavelengths of 492 and $525 \mathrm{~nm}$, respectively.

\section{Measurement of Macropinocytosis}

To examine the process of macropinocytosis, cells were allowed to adhere to coverslips and were exposed to FITC-dextran or Texas Red-dextran ( $2 \mathrm{mg} / \mathrm{ml}$ in growth medium) for $2 \mathrm{~min}$. The labeled cells were then fixed with formaldehyde $(1 \%$ [vol/vol] in growth medium) and then visualized by fluorescence microscopy with the use of an Olympus epifluorescence microscope as described (Seastone et al., 1998, 1999). The number of cells with macropinosomes (labeled vesicles $>0.5 \mu \mathrm{m}$ ) was scored visually.

\section{Measurement of Endosomal pH}

Endosomal $\mathrm{pH}$ in living $D$. discoideum cells was measured by the dual excitation ratio method with FITC-dextran as a $\mathrm{pH}$ probe (Cardelli et al., 1988). Cells were exposed to FITC-dextran (10 mg/ $\mathrm{ml}$ ) for $10 \mathrm{~min}$ (pulse) and chased in marker-free HL5 medium for $60 \mathrm{~min}$. At the indicated times, the cells were collected by centrifugation, washed, and resuspended in $50 \mathrm{mM} 2-(\mathrm{N}$-morpholino)ethanesulfonic acid ( $\mathrm{pH}$ 6.5) at a concentration of $3 \times 10^{6}$ cells $/ \mathrm{ml}$. Cell-associated fluorescence was measured as described above with the use of fluorescent excitation wavelengths of 450 and $495 \mathrm{~nm}$ and an emission wavelength of $520 \mathrm{~nm}$. The fluorescence excitation ratio at 495 and $450 \mathrm{~nm}(495 / 450 \mathrm{~nm})$ was calculated, and endosomal $\mathrm{pH}$ was determined from an in vitro standard curve of FITC-dextran in a $\mathrm{pH}$ range of $4-7$.

\section{Determining Processing Kinetics, Steady-State Distribution, and Rate of Secretion of $\alpha$-Mannosidase}

To measure the rate of processing of $\alpha$-mannosidase, logarithmically growing cells were collected, resuspended to $10^{7}$ cells $/ \mathrm{ml}$, and 
pulse labeled with $\left[{ }^{35} \mathrm{~S}\right]$ methionine $(700 \mu \mathrm{Ci} / \mathrm{ml})$. At various times, cells were collected and radiolabeled $\alpha$-mannosidase was immunoprecipitated from cell extracts and supernatants with the mAb $2 \mathrm{H} 9$. Precipitates were subjected to SDS-PAGE followed by fluorography.

To determine the steady-state distribution of lysosomal $\alpha$-mannosidase activity, logarithmically growing cells were separated into cellular (intracellular) and media (extracellular) fractions by centrifugation. Cellular fractions were lysed with $0.5 \%$ (vol/vol) Triton $\mathrm{X}-100$, and both intracellular and extracellular fractions were assayed for $\alpha$-mannosidase activity as described (Free and Loomis, 1974).

To measure the rate of secretion of $\alpha$-mannosidase, log-phase cells were harvested by centrifugation and resuspended at a concentration of $5 \times 10^{6}$ cells $/ \mathrm{ml}$ in fresh HL5 medium. A 1 -ml sample $(5 \times$ $10^{6}$ cells) was harvested by centrifugation at the times indicated (see RESULTS). The level of $\alpha$-mannosidase activity was measured in the supernatant (extracellular) or in the pellets of cells lysed by the addition of $1 \mathrm{ml}$ of $0.5 \%$ ( $\mathrm{vol} / \mathrm{vol}$ ) Triton X-100 (intracellular) as described (Free and Loomis, 1974).

\section{Measurement of Phagocytosis}

Log-phase cells were harvested as described above and resuspended at a concentration of $3 \times 10^{6}$ cells $/ \mathrm{ml}$ in fresh HL5 medium supplemented with carboxylate-modified crimson fluorescence latex microspheres ( $1 \mu \mathrm{m}$; Molecular Probes, Eugene, OR). The particle-to-cell ratio was 50:1. Resuspended cells were shaken at 120 $\mathrm{rpm}$, and phagocytosis was allowed to proceed at room temperature for $1 \mathrm{~h}$. At the times indicated (see RESULTS), $1-\mathrm{ml}$ samples $\left(3 \times 10^{6}\right.$ cells) were harvested by centrifugation, washed, and stored on ice as described above. For fluorescence measurements, the cells were lysed and diluted as described above. Cell-associated fluorescence was measured as described above with excitation and emission wavelengths of 595 and $625 \mathrm{~nm}$, respectively.

To rule out the possibility that surface changes of profilin-null cells resulted in enhanced binding but not enhanced phagocytosis of bacteria, we treated Ax2 and profilin-null cells, which had been incubated with fluorescein-labeled bacteria, with ethidium bromide, which binds to exposed (not internalized) bacteria and allows them to fluoresce in the rhodamine channel as well as in the fluorescein channel. Treated cells were then examined by fluorescence microscopy with the use of an Olympus epifluorescence microscope as described (Seastone et al., 1998, 1999).

\section{Measurement of F-Actin}

F-actin was determined with the use of TRITC-labeled phalloidin (Fluka, Neu-Ulm, Germany) as described (Haugwitz et al., 1994). Log-phase amebae $\left(2 \times 10^{5}\right)$ were harvested and lysed in buffer containing $1 \% \mathrm{NP}-40,2 \mathrm{mM} \mathrm{MgCl} 2,150 \mathrm{mM} \mathrm{KCl}, 10 \mathrm{mM} \beta$-glycerophosphate, $5 \mathrm{mM}$ ATP, $10 \mathrm{mM}$ HEPES (pH 7.2), $1 \mathrm{mM}$ benzamidine, $0.5 \mathrm{mM}$ PMSF, $4 \mathrm{mM} \mathrm{KH}_{2} \mathrm{PO}_{4}$, and $0.75 \mu \mathrm{M}$ TRITC-phalloidin. An equal aliquot was lysed in $1 \%$ SDS and used for protein determination as described above. After $60 \mathrm{~min}$, the samples were centrifuged at $150,000 \times g$ for $15 \mathrm{~min}$ with the use of a tabletop ultracentrifuge (Optima, Beckman Instruments, Palo Alto, CA). The pellets were extracted for $12 \mathrm{~h}$ in $100 \mu \mathrm{l}$ of methanol at $4^{\circ} \mathrm{C}$, and after an additional centrifugation step, the fluorescence was measured in an Aminco Bowman fluorimeter (Sopra, Buettelborn, Germany) at an excitation wavelength of $540 \mathrm{~nm}$ and an emission wavelength of $575 \mathrm{~nm}$. Because the cell sizes of the mutant strains differ from that of wild-type Ax2 cells, we calculated the F-actin content on the basis of protein concentration, not cell number. Alternatively, pellets and supernatants were subjected to SDS-PAGE and immunoblotting with the use of anti-actin antibody, and the relative actin content was determined by scanning densitometry of the gels.

\section{Immunofluorescent Cell Staining}

Macropinosomes were labeled by pulsing cells attached to coverslips with $5 \mathrm{mg} / \mathrm{ml}$ fixable tetramethylrhodamine-dextran (TR-dex- tran) in growth medium for $2 \mathrm{~min}$. Cells were fixed (Temesvari et al., 1996c), permeabilized, and then incubated with antibodies to DdLIMP followed by the addition of FITC-conjugated secondary antibody. Cells were visualized with the use of an Olympus (Tamarac, FL) epifluorescence microscope as described (Seastone et al., 1998, 1999).

\section{Statistical Analysis}

Student's $t$ test was performed with the use of the computer program GraphPAD Instat (version 1.12a, IBM; Armonk, NY)

\section{RESULTS}

\section{Profilin-null Mutants Are Defective in Pinocytosis and Macropinocytosis}

To determine if profilin regulates pinocytosis, the fluorescent fluid phase marker FITC-dextran was used to measure the ability of the wild-type cells and cells null for profilin to internalize fluid phase from the surrounding milieu. The parental cell line $(\mathrm{A} \times 2)$ and the mutant cell line $\left(\mathrm{pI} / \mathrm{II}^{-}\right.$, in which both profilin genes have been disrupted [Haugwitz et al., 1994]) were incubated in growth medium with $2 \mathrm{mg} / \mathrm{ml}$ FITC-dextran. Intracellular fluorescence was measured as described in MATERIALS AND METHODS, and the volume of fluid phase internalized per milligram of protein was plotted (Figure 1A). The profilin-null cell line, $p I / I I^{-}$, exhibited an average pinocytosis rate $(0.09 \pm 0.02 \mu l$ medium $\cdot \mathrm{mg}^{-1}$ protein $\cdot \mathrm{min}^{-1} ; \mathrm{n}=4$ ) that was $\sim 60 \%$ lower than that of the parental cell line, Ax2 $(0.24 \pm 0.06 \mu \mathrm{l}$ medium $\cdot \mathrm{mg}^{-1}$ protein $\cdot \min ^{-1} ; \mathrm{n}=4$ ). These results suggest that profilin is required for efficient pinocytosis of fluid phase.

In Dictyostelium, macropinocytosis accounts for the majority of total fluid phase uptake of the cell (Hacker et al., 1997). This process is characterized by uptake of fluid phase into large vesicles $(>0.5 \mu \mathrm{m})$ and is dependent on PI 3-kinase activity (Rupper et al., 1998). To further characterize profilindependent pinocytosis, we examined macropinocytosis in the mutant $\mathrm{pI} / \mathrm{II}^{-}$and the parental Ax2 cell lines. Macropinosomes were visualized by incubating the cells on coverslips for 2 min with FITC-dextran. The cells were then fixed with formaldehyde and visualized by fluorescence microscopy, and the number of cells containing macropinosomes (vesicles $>0.5 \mu \mathrm{m}$ ) was enumerated (Figure 1, B and C). Approximately $86 \%$ of parental cells exhibited visible FITClabeled macropinosomes, and most cells contained more than one macropinosome, whereas $<50 \%$ of $\mathrm{pI} / \mathrm{II}^{-}$cells displayed fluorescent macropinosomes. The difference in volume internalized via macropinocytosis is even greater when one considers that macropinosomes were larger in size and more numerous in the mutant than in the wild type. Together, these results suggest that profilin is required for efficient pinocytosis of fluid phase and macropinocytosis of fluid phase.

\section{Profilin-null Mutants Are Defective in Intracellular Fluid Phase Movement and Exocytosis}

In $D$. discoideum, fluid phase markers are ingested into nearly neutral macropinosomes and pinosomes (O'Halloran and Anderson, 1992; Aubry et al., 1993; Padh et al., 1993; Ruscetti et al., 1994; Hacker et al., 1997) that undergo fission 


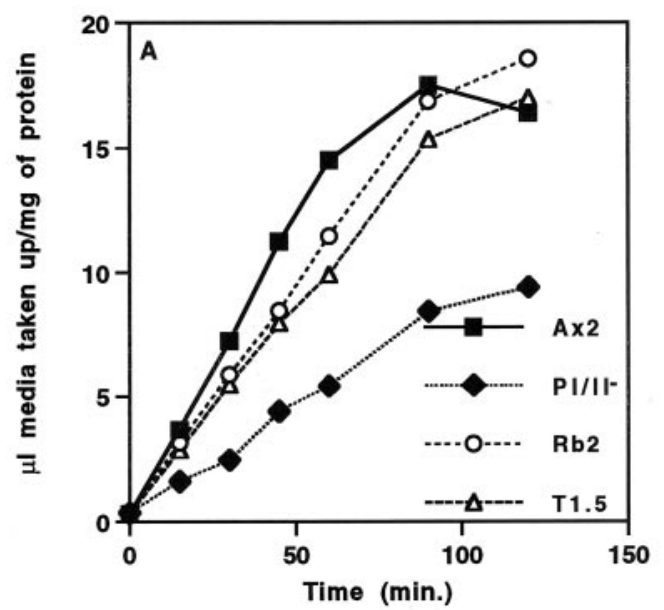

B
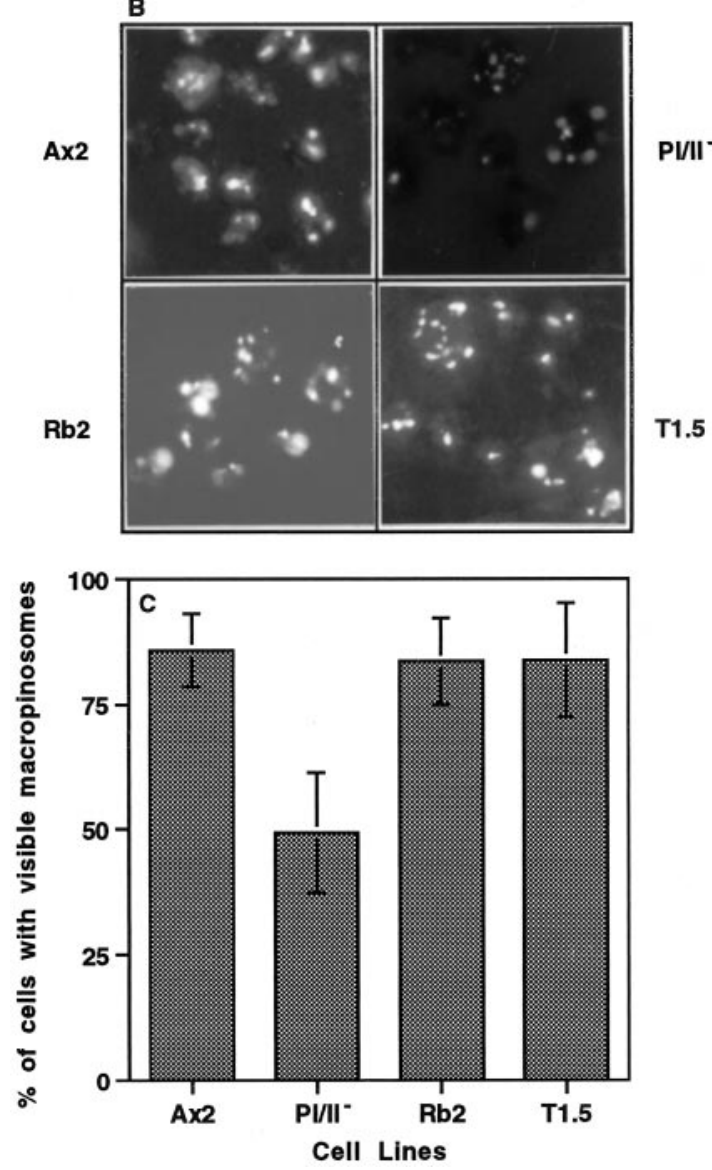

Figure 1. Profilin-null cells are defective in pinocytosis, and disruption of $\operatorname{lmp} A$ in a profilin-null background rescues this phenotype. (A) To measure the rate of pinocytosis, the parental cell line (Ax2) and three mutant cell lines ( $p I / I I^{-}, \mathrm{T} 1.5$, and $\left.\mathrm{Rb} 2\right)$ were incubated in growth medium with $2 \mathrm{mg} / \mathrm{ml}$ FITC-dextran. The last two strains (T1.5 and Rb2) contain mutations that inactivate both profilin genes as well as the $\operatorname{lmp} A$ gene described elsewhere in RESULTS. Intracellular fluorescence was measured at the times indicated, as described in MATERIALS AND METHODS, and the volume of fluid phase internalized per milligram of protein was plotted. The rate of fluid phase uptake in all cell lines was linear over $60 \mathrm{~min}$, and and then fusion reactions to generate acidic lysosomal vesicles (Rodriquez-Paris et al., 1993). Subsequently, fluid phase enters nonacidic postlysosomes before complete egestion from the cell (Aubry et al., 1993; Padh et al., 1993). No rapid fluid phase recycling compartment has been observed in this organism, and the linear process of fluid phase movement through all of the compartments takes at least 50 min (Aubry et al., 1993; Padh et al., 1993). To determine if profilin plays a role in exocytosis of fluid phase, a process that we and others have determined to be regulated by actin (Temesvari et al., 1996c; Jenne et al., 1998), we loaded wild-type and mutant cells to steady state with FITC-dextran and resuspended them in fresh medium. The release of fluid phase was monitored by measuring the decrease in intracellular fluorescence over time. As seen in Figure 2A, the release of the fluid phase marker began immediately upon initiation of the chase for wild-type Ax2 cells and was nearly complete by $2 \mathrm{~h}$. In contrast, exocytosis of fluid phase in the $\mathrm{pI} / \mathrm{II}^{-}$null cell line was significantly delayed relative to wild-type cells, suggesting that functional profilin was required for efficient efflux of fluid phase.

To determine the trafficking step at which fluid phase movement was delayed in the $\mathrm{pI} / \mathrm{II}^{-}$null cell line, we monitored the movement of FITC-dextran (fluid phase marker and $\mathrm{pH}$ probe) after a 10-min pulse through endosomal compartments by measuring the temporal changes in compartmental $\mathrm{pH}$ with the use of a dual excitation ratio method, as described in MATERIALS AND METHODS (Figure 2B). In the parental cell line, Ax2, FITC-dextran reached the most acidic compartments ( $\mathrm{pH} 4.5)$ by $6.7 \pm 2.9$ min $(n=3)$ of chase; it then moved from this acidic compartment to nonacidic postlysosomes within $60 \mathrm{~min}$ of chase. On the other hand, in $\mathrm{pI} / \mathrm{II}^{-}$cells, the rate of movement of fluid phase from slightly acidic early endosomes to acidic lysosomes was significantly delayed, requiring $\sim 18.3 \pm 1.4 \mathrm{~min}(\mathrm{n}=3)$ of chase. These data suggest that lack of profilin leads to a delay in fluid phase trafficking at a step that is early in the endocytic pathway before acidic lysosomes. Alternatively, the absence of profilin may not

the initial rate of fluid phase uptake measured over $30 \mathrm{~min}$ was $0.24 \pm 0.06 \mu \mathrm{l}$ medium $\cdot \mathrm{mg}^{-1}$ protein $\cdot \mathrm{min}^{-1}, 0.08 \pm 0.02 \mu \mathrm{l}$

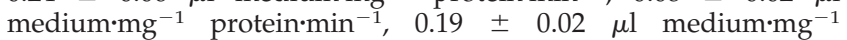
protein $\cdot \mathrm{min}^{-1}$, and $0.17 \pm 0.02 \mu \mathrm{l} \mathrm{medium} \cdot \mathrm{mg}^{-1}$ protein $^{-\mathrm{min}^{-1}}$ for $\mathrm{Ax2}, \mathrm{pI} / \mathrm{II}^{-}, \mathrm{Rb} 2$, and $\mathrm{T} 1.5$, respectively (mean $\pm \mathrm{SD}, \mathrm{n}=4$ for all). Statistical analysis indicated that the rate of fluid phase uptake by the $p I / I I^{-}$cell line was significantly lower than that by the parental Ax2 cell line $(p=0.0019, n=4)$ and that the rates of uptake of fluid phase by the $\mathrm{Rb} 2$ and $\mathrm{T} 1.5$ cell lines were not significantly different from that of $\mathrm{Ax} 2(\mathrm{p}>0.05, \mathrm{n}=4)$. ( $\mathrm{B}$ and $\mathrm{C})$ To examine the process of macropinocytosis, cells that adhered to coverslips were labeled for $2 \mathrm{~min}$ with FITC-dextran $(2 \mathrm{mg} / \mathrm{ml}$ in growth medium). The labeled cells were fixed with formaldehyde $(1 \%$ [vol/vol] in growth medium) and then visualized by fluorescence microscopy (B), and the number of cells with macropinosomes was scored visually (C). Statistical analysis indicated that $49.3 \pm 11.0 \%(\mathrm{n}=100)$ of $\mathrm{pI} / \mathrm{II}^{-}$ cells demonstrated macropinosomes, which was significantly lower $(\mathrm{p} \leq 0.0003)$ than the percentage of parental $(85.9 \pm 7.2 \%, \mathrm{n}=100)$, $\mathrm{Rb} 2(83.6 \pm 8.6 \%, \mathrm{n}=100)$, or T1.5 $(83.9 \pm 11.3 \%, \mathrm{n}=100)$ cells with macropinosomes. Moreover, the percentage of Ax2, Rb2, and T1.5 cell lines displaying macropinosomes was not significantly different from one another $(\mathrm{p}>0.05)$. 
Figure 2. Profilin plays a role in fluid phase exocytosis and secretion of lysosomal hydrolases, and disruption of $\operatorname{Imp} A$ in a profilin-null background rescues exocytosis only. (A) Exocytosis was measured as described in MATERIALS AND METHODS. Intracellular fluorescence was measured, and the percentage of total FITC-dextran remaining in cells was plotted over time $(3 \mathrm{~h})$. The data correspond to the mean $(n=7)$ for all cell lines. At 45 min of chase, $47.9 \pm 6.2 \%$ of the total fluid phase marker remained in the parental Ax2 cell line, whereas significantly more marker $(98.6 \pm 3.2 \%$, p < 0.0001 ) remained in the $\mathrm{pI} / \mathrm{II}^{-}$cell line. (B) To measure intraendosomal $\mathrm{pH}$, the parental Ax2 cell line and the three mutant cell lines were incubated with $2 \mathrm{mg} / \mathrm{ml}$ FITC-dextran for $10 \mathrm{~min}$, washed twice with fresh medium, and incubated in fresh medium for 90 $\min$. At the indicated times, intravesicular $\mathrm{pH}$ was determined by a standard dual excitation-emission strategy, as described previously (Cardelli et al., 1988). The data correspond to the mean $(\mathrm{n}=3)$ for all cell lines. In $\mathrm{pI} / \mathrm{II}^{-}$, fluid phase reached the lysosomal compartment (compartment of lowest $\mathrm{pH} ; \mathrm{pH}=4.60 \pm 0.21, \mathrm{n}=3)$ in $18.3 \pm$ $1.4 \mathrm{~min}$, which is significantly $(\mathrm{p}=$ 0.0033 ) slower that the time required for fluid phase to reach the lysosomal compartment $(\mathrm{pH}=4.53 \pm 0.06, \mathrm{n}=$ 3) in Ax2 cells (6.7 $\pm 2.9 \mathrm{~min})$. The time required for fluid phase to reach the lysosomal compartment in the $\mathrm{Rb} 2(9.2 \pm 1.4 \mathrm{~min}, \mathrm{n}=3)$ and $\mathrm{T} 1.5$ $(6.7 \pm 1.4 \mathrm{~min}, \mathrm{n}=3)$ cell lines was not significantly different from that required by the parental Ax2 cell line. (C) To determine the distribution of lysosomal $\alpha$-mannosidase activity, logarithmically growing cells were separated into cellular and media fractions by centrifugation and lysed with $0.5 \%$ Triton X-100, and each fraction was assayed for $\alpha$-mannosidase activity, as described previously (Cardelli et al., 1988). Extracellular enzyme activity was reported as a percentage of the total enzyme activity. (D) To measure the rate of secretion of $\alpha$-mannosidase, growth medium was removed from growing cells and replaced with fresh medium. Samples were removed at the times indicated, the cells were pelleted and solubilized, and both cells and supernatants were assayed for $\alpha$-mannosidase activity. The graph represents the percentage of secreted enzyme activity over time. Statistical analysis demonstrated that the percentage of intracellular $\alpha$-mannosidase activity in, and the rate of secretion of $\alpha$-mannosidase activity from, the $\mathrm{pI} / \mathrm{II}^{-}, \mathrm{Rb} 2$, and T1.5 cell lines were significantly lower than those of the parental Ax2 cell line $(\mathrm{p}<0.0001)$.

delay the movement of material to lysosomes, but the rate of acidification may be slower.

\section{Profilin-null Mutants Are Defective in Secretion of Hydrolases}

The role of profilins in the secretion of mature lysosomal enzymes from postlysosomes was also examined. This is a relevant experiment because efflux of fluid phase is, in contrast to secretion of hydrolases, not a regulated process in Dictyostelium. Although fluid phase markers and hydrolases reside in the same endosomal compartments, lysosomal enzymes are selectively retained in cells in growth medium, whereas fluid phase markers are completely secreted. Starvation of cells increases the rate of secretion of lysosomal hydrolases fivefold, but it has no affect on the rate of fluid phase efflux (Cardelli, 1993). Furthermore, mutants have been described that differentially affect secretion of fluid phase versus secretion of lysosomal enzymes (Temesvari et al., 1996a; Buczynski et al., 1997a). To measure secretion of lysosomal enzymes, we first determined the steady-state intracellular and extracellular distribution of the lysosomal hydrolase $\alpha$-mannosidase in cells during logarithmic growth (Figure 2C). Approximately 25\% of the total enzyme activity was intracellular in the Ax2 parental cell line growing in HL5 growth medium. In contrast, $>90 \%$ of total $\alpha$-mannosidase activity was found to be intracellular in the $p I / I I^{-}$cell line, indicating a severe defect during growth in secretion of $\alpha$-mannosidase by this mutant. The rate of $\alpha$-mannosidase secretion was also measured to confirm the secretion defect observed for the $p I / I I^{-}$cells. The $p I / I I^{-}$cells exhibited a secretion rate in growth medium that was significantly lower than that of 

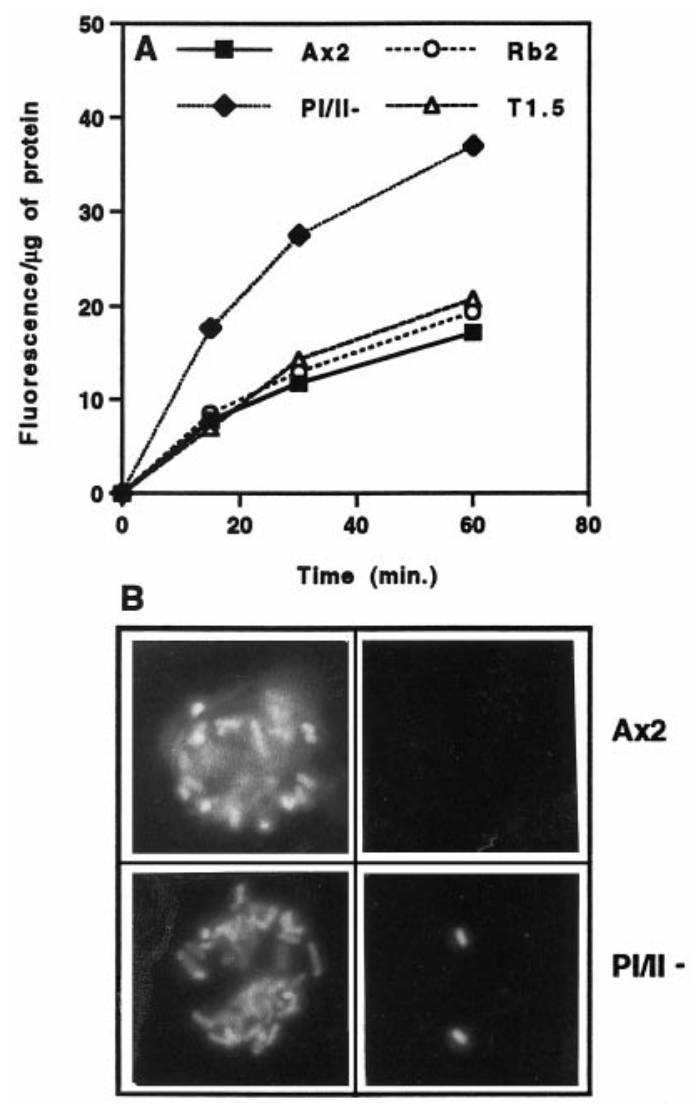

\section{F-channel R-channel}

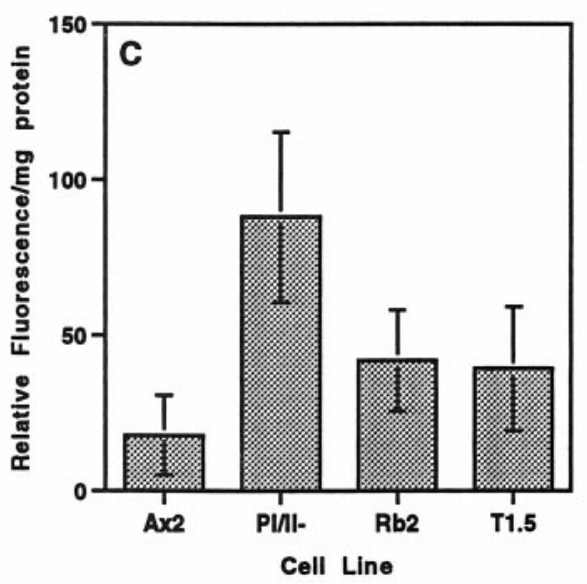

Figure 3. Profilin acts as a negative regulator of phagocytosis, and disruption of $\operatorname{lmp} A$ in a profilin-null background suppresses this action. (A) To measure the rate of phagocytosis, the parental cell line (Ax2) and the three mutant cell lines were incubated in growth medium with fluorescent latex beads $(1 \mu \mathrm{m} ; 50$ beads/cell). Intracellular fluorescence was measured at the times indicated, as described in MATERIALS AND METHODS, and the amount of fluorescence internalized per microgram of protein was plotted. Statistical analysis indicated that the rate of phagocytosis seen in the $\mathrm{pI} / \mathrm{II}^{-}$cell line was significantly higher than that seen in the parental Ax2 cell line $(p=0.0110, n=3)$ and that the rates of uptake of the parental Ax2 cells. These data indicate that functional profilin is required for the efficient secretion of lysosomal hydrolases and fluid phase.

\section{Profilin-null Mutants Are More Active in Phagocytosis}

$D$. discoideum cells can also acquire nutrients by phagocytosis, a process that is highly dependent on the regulation of F-actin (Temesvari et al., 1996c; Jenne et al., 1998). To determine if functional profilin is required for phagocytosis, we used fluorescence-labeled (crimson) latex microspheres to assess the ability of parental and mutant cell lines to take up large particles $(1 \mu \mathrm{m})$ from the surrounding growth medium. Figure $3 \mathrm{~A}$ indicates that the $\mathrm{pI} / \mathrm{II}^{-}$null cell line internalized latex beads at a rate that was twofold to threefold higher than that of parental Ax2 cells. To confirm the enhanced phagocytic capability of the profilin-null mutants with a physiologically relevant particle, the parental and null cell lines were allowed to phagocytose fluorescein-labeled Escherichia coli. The labeled cells were visualized by fluorescence microscopy, and the number of internalized bacteria was counted. It was determined that the parental cell line accumulated $8.8 \pm 3.2(\mathrm{n}=21)$ bacteria after $30 \mathrm{~min}$ of incubation, whereas $\mathrm{pI} / \mathrm{II}^{-}$null cell lines took up a significantly greater number of bacteria $(18 \pm 5.5 ; n=16)$ in the same period. Comparable results were observed if the uptake rate of fluorescent bacteria was measured with the use of a fluorimeter and the number of bacteria taken up was normalized to a constant amount of cellular protein (our unpublished results).

In addition, to rule out the possibility that surface changes of $\mathrm{pI} / \mathrm{II}^{-}$null cells resulted in enhanced binding, but not phagocytosis, of bacteria, we performed the following control experiment. Ax2 and mutant cell lines that had been incubated with fluorescein-labeled bacteria were treated with ethidium bromide, which binds to exposed (not internalized) bacteria and causes them to fluoresce in the rhodamine channel as well as the fluorescein channel. It was

fluorescent beads by the Rb2 and T1.5 cell lines (in which both the profilin genes and the DdLIMP gene have been disrupted) were not significantly different from that of Ax2 (p > 0.05, $n=3)$. (B) This experiment was done to rule out the possibility that surface changes of profilin-null cells resulted in enhanced binding but not enhanced phagocytosis of bacteria. Ax2 and profilin-null cells that had been incubated with fluorescein-labeled bacteria were treated with ethidium bromide, which binds to exposed (not internalized) bacteria and allows them to fluoresce in the rhodamine (R) channel as well as the fluorescein $(\mathrm{F})$ channel. Treated cells were then examined by fluorescence microscopy with the use of an Olympus epifluorescence microscope, as described (Seastone et al., 1998, 1999). (C) Quantitation of the F-actin fraction of Ax2 and the three mutant cell lines by measuring the relative rhodamine fluorescence per milligram of total protein. Mean \pm SD was calculated from 14 assays for each strain: Ax2, $17.9 \pm 12.9 ; \mathrm{pI} / \mathrm{II}^{-}, 88.0 \pm 27.3$; Rb2, $41.9 \pm 16.3$; T1.5, $39.2 \pm 19.9$. Statistical analysis indicated that the F-actin content in the $\mathrm{pI} / \mathrm{II}^{-}$cell line was significantly higher than that in the parental Ax2 cell line ( $\mathrm{p}<0.001, \mathrm{n}=14)$. The partially suppressed F-actin levels in the $\operatorname{lmp} A$ mutants $\mathrm{Rb} 2$ and T1.5 were significantly lower than that in the $p I / I I^{-}$cell line $(\mathrm{p}<0.001, \mathrm{n}=14)$ but still higher than that in the Ax2 strain $(\mathrm{p}<0.001, \mathrm{n}=14) . \mathrm{Rb} 2$ and T1.5 were not significantly different from each other $(p>0.05, n=14)$. 
determined that relatively few bacteria were able to fluoresce in the rhodamine channel, indicating that they were not available for ethidium bromide binding because they had been internalized (Figure 3B). The bacteria in wild-type cells appear brighter than those in the mutant cells because of different exposure times. This confirms that the $\mathrm{pI} / \mathrm{II}^{-}$null cell line has an enhanced phagocytic capability.

\section{Inactivation of DdlmpA Suppresses Most But Not All of the Profilin-null Endocytic Alterations}

It has been reported that genetic inactivation of the $\operatorname{lmp} A$ gene encoding a protein that also binds phosphoinositides reverses the developmental defect observed in the profilinnull cells (Karakesisoglou et al., 1999). Various aspects of endosomal trafficking were assayed in the $\operatorname{lmpA} / \mathrm{pI} / \mathrm{pII} I^{-}$triple null mutant as described above. Interestingly, the fluid phase endocytic defect observed in the profilin-null mutant was suppressed in the triple mutant (Figure 1A). The average rates of pinocytosis for the $\mathrm{Rb} 2$ strain $(\operatorname{lmp} A$ gene disrupted by REMI) and the T1.5 strain $(\operatorname{lmp} A$ gene disrupted by targeted gene disruption) were $0.19 \pm 0.02 \mu l$ medium $\cdot \mathrm{mg}^{-1}$ protein $\cdot \mathrm{min}^{-1}(\mathrm{n}=4)$ and $0.17 \pm 0.02 \mu \mu \mathrm{l}$ medium $\cdot \mathrm{mg}^{-1}$ protein $\cdot \mathrm{min}^{-1}(\mathrm{n}=4)$, respectively, compared with $0.24 \pm 0.06 \mu \mathrm{l}$ medium $\cdot \mathrm{mg}^{-1}$ protein $\cdot \min ^{-1}(\mathrm{n}=$ 4) for the wild type and $0.09 \pm 0.02 \mu \mu \mathrm{l} \mathrm{medium} \cdot \mathrm{mg}^{-1}$ protein $\cdot \min ^{-1}(\mathrm{n}=4)$ for the $\mathrm{pI} / \mathrm{II}^{-}$null mutant. In particular, the macropinocytic defect observed in the profilin-null cells was suppressed in those cell lines that also lacked DdLIMP; $\sim 84 \%$ of Rb2 or T1.5 cells exhibited visible macropinosomes after short exposures to fluorescent fluid phase markers, which is comparable to the suppression observed in wild-type cells (Figure 1, B and C). These data also further advance the concept of a functional connection between profilin and DdLIMP (Karakesisoglou et al., 1999) and suggest that DdLIMP may antagonize the role of profilin in pinocytosis of fluid phase.

Interestingly, the defect in exocytosis of fluid observed in the profilin-null cell line was partially reversed by disruption of the $\operatorname{lmp} A$ gene (Figure 2A). However, codisruption of the $\operatorname{lmp} A$ gene in the profilin-minus background did not reverse the secretion defect (Figure 2, C and D), suggesting that DdLIMP is not important in late vesicle trafficking events that lead to the secretion of hydrolases. Finally, stimulation of phagocytosis was completely reversed in $\mathrm{pI} / \mathrm{II}^{-}$ null cell lines also lacking DdLIMP (Figure 3A), indicating that profilin and DdLIMP may also be functionally connected in the regulation of phagocytosis.

Both macropinocytosis and phagocytosis are dependent on F-actin, so we wanted to determine if a disruption of DdLIMP, which suppresses the profilin-dependent changes in these processes, would also reverse the increase in F-actin observed in the $\mathrm{pI} / \mathrm{II}^{-}$strain. F-actin levels were measured in the wild-type and mutant cell lines as described previously (Haugwitz et al., 1994). The cells were lysed in the presence of TRITC-phalloidin, the F-actin was sedimented at $150,000 \times g$, and the pellets and supernatants were subjected to fluorimetry or SDS-PAGE. Fluorescence measurements indicated that the profilin-minus strain harbored more Factin than the parental Ax2 cell line and that this phenotype was partially reversed in the Rb2 and T1.5 cell lines (Figure 3C). Western blot analysis with antibodies recognizing actin corroborated these data and also demonstrated that the amount of total cellular actin $(F+G)$ in all cell lines was not altered significantly (our unpublished results).

\section{DdLIMP Can Localize to Macropinosomes}

Immunofluorescence microscopy has indicated that DdLIMP was localized to small punctate structures and large vesicles and colocalized in some of these structures with $\beta$-COP, a COPI coatomer protein, as judged by staining with a heterologous $\beta$-COP antibody (Karakesisoglou et al., 1999). $\beta$-COP has been found to play a role early in the secretory pathway as well as in the early-to-late endosomal vesicle transfer (Whitney et al., 1995). Moreover, sucrose density gradient centrifugation indicated that DdLIMP comigrated with membranes of a density comparable to that reported for early endosomes or postlysosomes (Karakesisoglou et al., 1999). Therefore, to further define the DdLIMP-positive intracellular compartment, we labeled macropinosomes in Ax 2 cells by pulsing with fixable TR-dextran for $2 \mathrm{~min}$. Cells were fixed with formaldehyde, permeabilized, and then incubated with antibodies to DdLIMP. As indicated by the arrows in the micrographs shown in Figure 4, DdLIMP (B) colocalized with the fluid phase marker TR-dextran (C) in a patch-like pattern surrounding newly formed macropinosomes (phase contrast; A). This large patch-like vesicular staining pattern for DdLIMP has been observed previously (Karakesisoglou et al., 1999). The less than optimal fluorescence pattern for the TR-dextran is the result of the permeabilization necessary for the DdLIMP immunofluorescence. The observation that DdLIMP localizes to very early endocytic compartments is consistent with the observation that the defects early in the endocytic pathway in the profilinnull cell line could be suppressed by disruption of the gene encoding DdLIMP. The arrowhead in Figure 4C points to smaller DdLIMP-positive puncta that might represent lysosomes (see DISCUSSION).

\section{Disruption of $\operatorname{lmpA}$ in a Wild-Type Background Results in Decreases in Pinocytosis and Efflux of Fluid Phase But No Change in Phagocytosis Rates}

The localization of DdLIMP in the endosomal pathway combined with the genetic suppression data suggest that this protein may regulate endocytosis and endosomal membrane trafficking. To test this possibility, a previously described (Karakesisoglou et al., 1999) $\operatorname{lmp} A^{-}$strain generated in a wild-type background was functionally characterized. The rate of pinocytosis in the $\operatorname{lmp} A^{-}$strain (Figure 5A) was only $25 \%$ that in the wild-type strain (Figure 5A), whereas the rate of phagocytosis was slightly but not significantly reduced in the mutant versus the wild-type strain (Figure 5B). The rate of efflux of fluid phase was also greatly reduced in the mutant compared with the wild-type strain. For instance, $50 \%$ of the internalized fluid phase was released by wild-type cells $40 \mathrm{~min}$ into the chase period, whereas 130 min was required before $50 \%$ of the fluid was released from the $\operatorname{lmp} A$ null mutant (Figure 5C). Finally, internalized fluid remained in acidic compartments longer in the mutant than in the wild-type strain (Figure 5D), suggesting a block in transport at the lysosome-to-postlysosome step. 


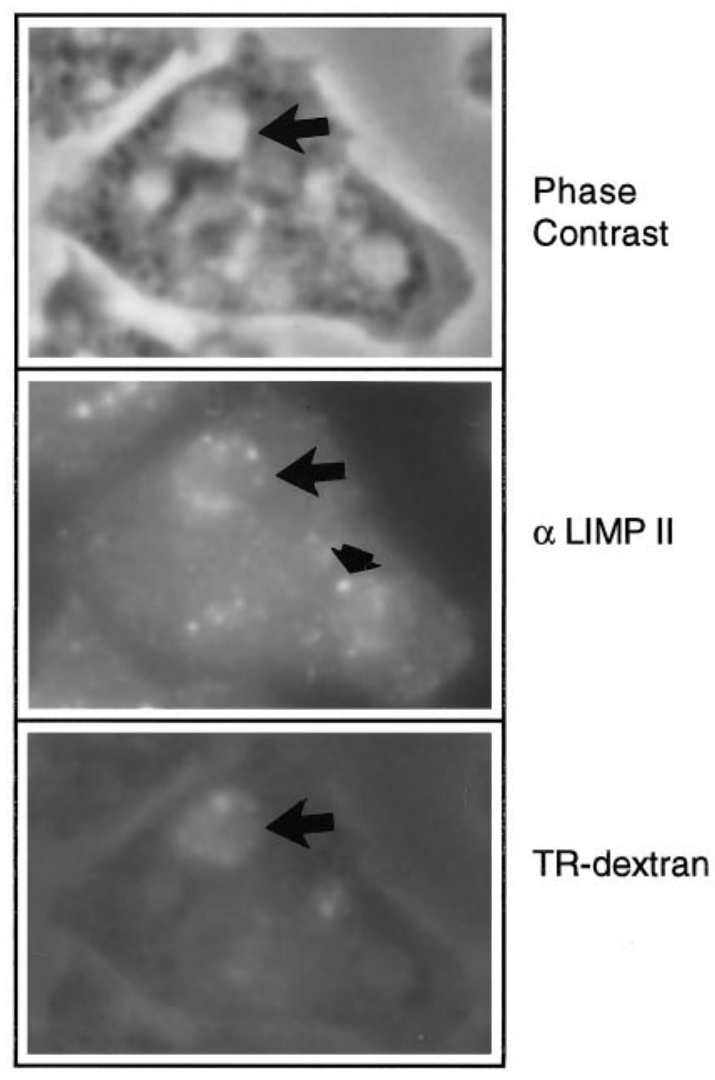

Figure 4. DdLIMP can localize to macropinosomes in wild-type Dictyostelium cells. Macropinosomes were labeled in growth medium by pulsing cells attached to coverslips with $5 \mathrm{mg} / \mathrm{ml}$ fixable TR-dextran for $2 \mathrm{~min}(\mathrm{C})$. Cells were fixed, permeabilized, and then incubated with antibodies to DdLIMP followed by the addition of FITC-conjugated secondary antibody (B). Cells were visualized with the use of an Olympus epifluorescence microscope, as described (Seastone et al., 1998, 1999). The large arrow points to a macropinosome (large vacuole in A) that is DdLIMP positive (B) and TRdextran positive $(\mathrm{C})$, and the small arrow points to one of a number of small DdLIMP-positive punctate structures.

\section{Profilin and DdLIMP Do Not Significantly Regulate the Transport or Targeting of Lysosomal Proteins}

To determine if the absence of profilin and DdLIMP also affected the transport of proteins along the biosynthetic pathway and/or targeting to lysosomes, wild-type, $\mathrm{pI} / \mathrm{II}^{-}$, and $\operatorname{lmp} A^{-}$cells were pulse labeled with [ $\left.{ }^{35} \mathrm{~S}\right]$ methionine for $20 \mathrm{~min}$ and chased for the times indicated in Figure 6. At various times, cells were separated from the supernatant, and $\alpha$-mannosidase was immunoprecipitated. The immune complexes were subjected to SDS-PAGE followed by fluorography. The fluorographs shown in Figure 6, A-C, represent one of three experiments. The rate of processing of the $140-\mathrm{kDa}$ precursor to the $80-\mathrm{kDa}$ intermediate and the 58and $60-\mathrm{kDa}$ mature forms was nearly identical for all three strains tested; the half-time for formation was $\sim 25 \mathrm{~min}$. The apparent faster processing of $\alpha$-mannosidase in the profilinnull mutant was not reproducibly observed. Furthermore, all three strains efficiently sorted the precursor from the biosynthetic pathway to compartments in which the 60- and $58-\mathrm{kDa}$ mature forms were formed. This result suggests that profilin and DdLIMP do not significantly influence the transport and targeting of proteins along the biosynthetic pathway to lysosomes and that their roles may be more confined to the endosomal pathway.

The rate of secretion of the radiolabeled mature forms of $\alpha$-mannosidase was reduced in the $p I / I I^{-}$null and $\operatorname{lmp} A$ null strains (Figure 6, A-C). Furthermore, as observed for the pI/II- null mutant and the triple mutant (Figure 2), in growth medium the $\operatorname{Imp} A$ mutant secreted lysosomal hydrolase activity more slowly compared with the wild type (Figure 6D).

\section{DISCUSSION}

In this report, we present data that support the hypothesis that profilin plays an important positive role in macropinocytosis, release of internalized fluid phase, and secretion of lysosomal hydrolases. Surprisingly, profilin appears to play a negative regulatory role in phagocytosis, i.e., in the absence of profilin, the rate of phagocytosis increases. Profilin does not significantly regulate trafficking along the secretory or lysosomal targeting pathways. Moreover, we have shown that the endocytic defects and phagocytic increases observed for the profilin-null cell line also could be suppressed by disrupting the gene encoding DdLIMP, suggesting that this protein may act as a negative regulator of profilin. As for yeast and Drosophila (Haarer et al., 1990; Cooley et al., 1992; Magdolen et al., 1993), lack of profilin in D. discoideum caused increased F-actin levels and changes in actin distribution. Unexpectedly, disruption of the $\operatorname{lmp} A$ gene by insertional mutagenesis ( $\mathrm{Rb} 2)$ or homologous recombination (T1.5) in the profilin-null cells not only restored defects in membrane trafficking but also reversed the increased F-actin levels. The mutant strains $\mathrm{Rb} 2$ and $\mathrm{T} 1.5$ contained an Factin-rich cortex and pseudopodia (our unpublished results), as did the wild-type controls, whereas profilin-minus cells were characterized by an abnormally thick F-actin rim in the cortex (Haugwitz et al., 1994). Finally, analysis of a $\operatorname{lm} p A$ null strain created in a wild-type strain further supported a role for DdLIMP in pinocytosis and endosomal membrane traffic.

Profilin is required for efficient release of fluid phase and lysosomal enzymes. Internalized fluid phase entered acidic compartments more slowly in profilin mutants than in wildtype cells. This would suggest that regulation of the actin cytoskeleton is important early in the endosomal pathway, consistent with other published studies. This delay in fluid movement early in the endosomal pathway could partially account for the delay in efflux of fluid phase; however, we propose that profilin also acts late in the endosomal pathway to regulate fusion of postlysosomes with the plasma membrane, perhaps by regulating actin polymerization. Others, in fact, have demonstrated that F-actin is associated with postlysosomes (Rauchenberger et al., 1997). Regulation of fusion could account for the reduction in fluid phase and lysosomal enzyme secretion, because postlysosomes represent the secretory compartment for hydrolases and the terminal compartment for fluid phase. Alternatively, the severe reduction in secretion of lysosomal hydrolases could be due to profilin acting in a negative manner to regulate the recy- 

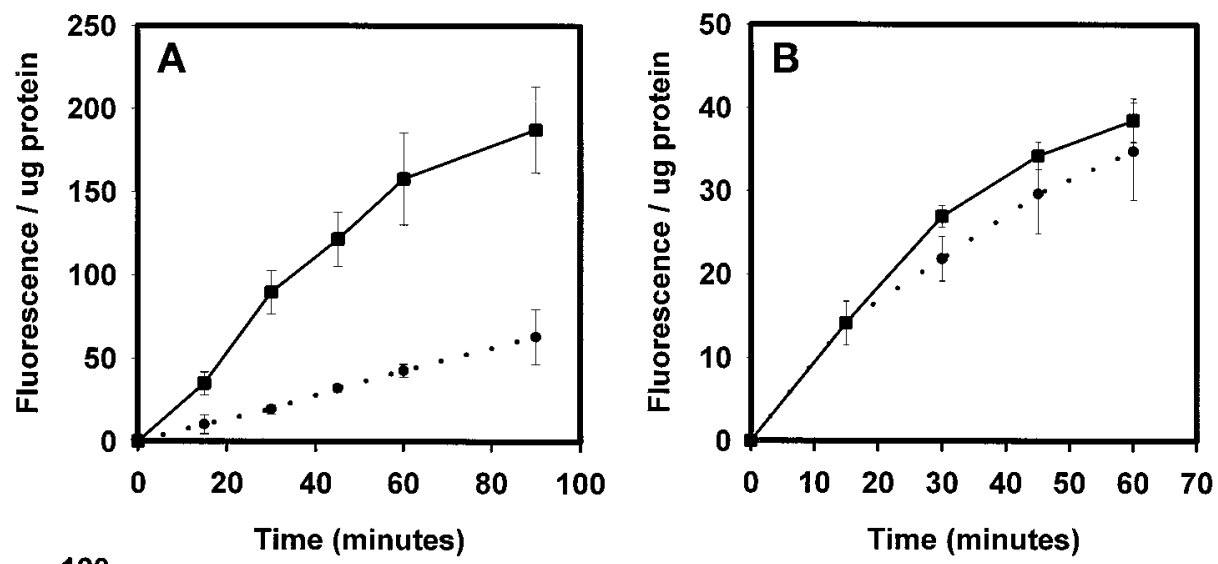

Figure 5. DdLIMP regulates endocytosis and fluid phase efflux. (A) Fluid phase endocytosis rates were measured in wild-type cells (घ) and $\operatorname{lmp} A$ null cells (0), as described in MATERIALS AND METHODS. (B) Rates of internalization of latex beads were measured in wild-type cells ( $\square$ ) and ImpA null cells (O). (C) Rates of fluid phase efflux were measured in wild-type cells ( $\mathbf{\square})$ and $\operatorname{lm} p A$ null cells (-), as described in MATERIALS AND METHODS. (D) The rates of transport of fluid phase through compartments of varying $\mathrm{pH}$ were measured in wild-type cells (ם) and $\operatorname{lmp} A$ null cells $(\mathbf{\bullet})$.
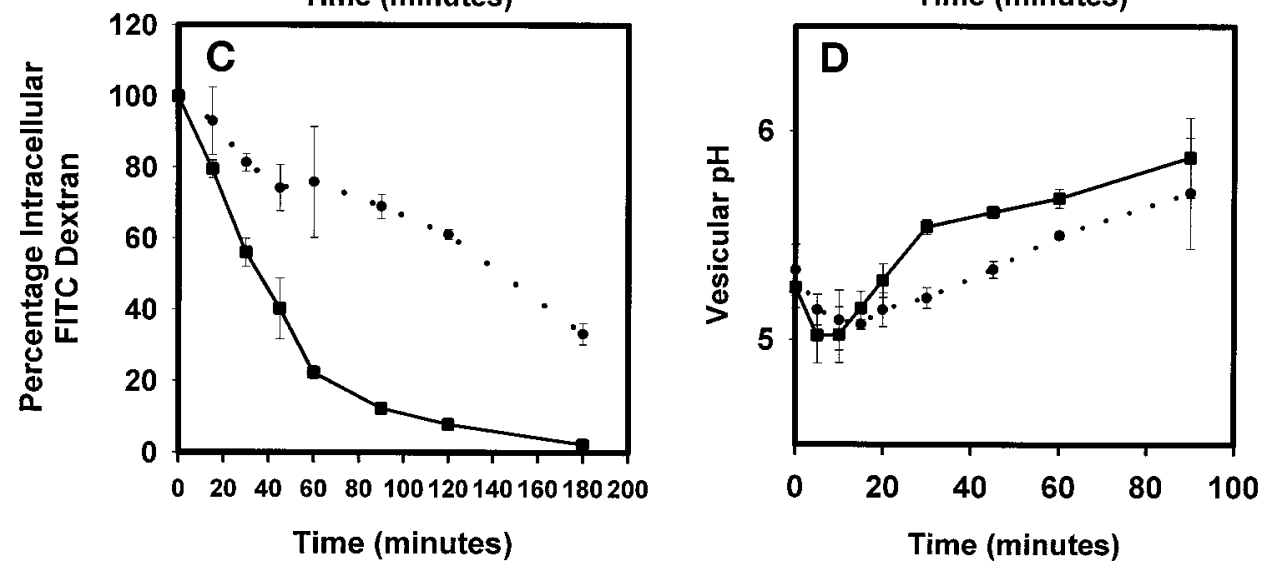

cling of hydrolases from postlysosomes and lysosomes. Accordingly, the absence of profilin would result in more efficient recycling of enzymes from postlysosomes and a subsequent reduction in secretion. Theoretically, profilin could be required for targeting of lysosomal hydrolases to lysosomes, and the absence of profilin could indirectly block secretion; however, a lysosomal enzyme, $\alpha$-mannosidase, was processed to mature subunits (an event that occurs in lysosomes) with normal kinetics

Like profilin, PI-3 kinases regulate macropinocytosis (Rupper et al., 1998), fluid phase efflux (Buczynski et al., 1997b), secretion of hydrolases (Buczynski et al., 1997b), and polymerization of F-actin (Buczynski et al., 1997b). Interestingly, profilin has been demonstrated to bind and activate PI 3-kinase (Singh et al., 1996; Bhargavi et al., 1998). Therefore, with regard to the regulation of macropinocytosis and endosomal traffic, one possibility is that profilin activates PI 3-kinase at the plasma membrane and on endosomal membranes, resulting in the formation of $\mathrm{PIP}_{3}$, which may be necessary for the production of macropinosomes and fluid phase efflux. PI 3-kinase may be recruited by binding to profilin or other proteins localized to the plasma membrane. These data are consistent with previous studies suggesting that profilin plays an important role in connecting phosphoinositide-mediated signal transduction pathways with changes in the actin cytoskeleton (Goldschmidt-Clermont et al., 1990; Sohn et al., 1995; Singh et al., 1996; Lambrechts et al., 1997; Bhargavi et al., 1998; Witke et al., 1998) that may be important in modulating macropinocytosis and endosomal membrane trafficking.

Why does the absence of profilin result in an increase in phagocytosis and a decrease in macropinocytosis even though these are morphologically similar processes driven by polymerization of F-actin? As mentioned previously, in addition to binding actin, profilin can also bind $\mathrm{PIP}_{2}$ and prevent its hydrolysis as well as inhibit PLC- $\gamma$ activation (Goldschmidt-Clermont et al., 1990; Sohn et al., 1995; Lambrechts et al., 1997). In Dictyostelium, PLC is thought to play an important role in phagocytosis (Seastone et al., 1999) by generating diacylglycerol from $\mathrm{PIP}_{2}$, which in turn is hypothesized to initiate actin polymerization (Shariff and Luna, 1992) and/or to activate guanine nucleotide exchange factors leading to activation of Rap1 (Seastone et al., 1999) and other small $G$ proteins. These small $G$ proteins may in turn stimulate the F-actin changes required to engulf large particles (Seastone et al., 1998). In the absence of profilin, there might be an increase in the amount of $\mathrm{PIP}_{2}$ substrate available for PLC activated upon particle binding, which would lead to increases in the rate of formation of diacylglycerol and in the rate of phagocytosis. Alternatively, the increased amount of cortical F-actin observed in profilin-null cells may supply G-actin monomers by depolymerization (action of cofilin-like molecules) and/or branching sites for the polymerization of new F-actin filaments that in turn may stimulate phagocytosis. In contrast, abundant cortical actin may inhibit macropinocytosis. 


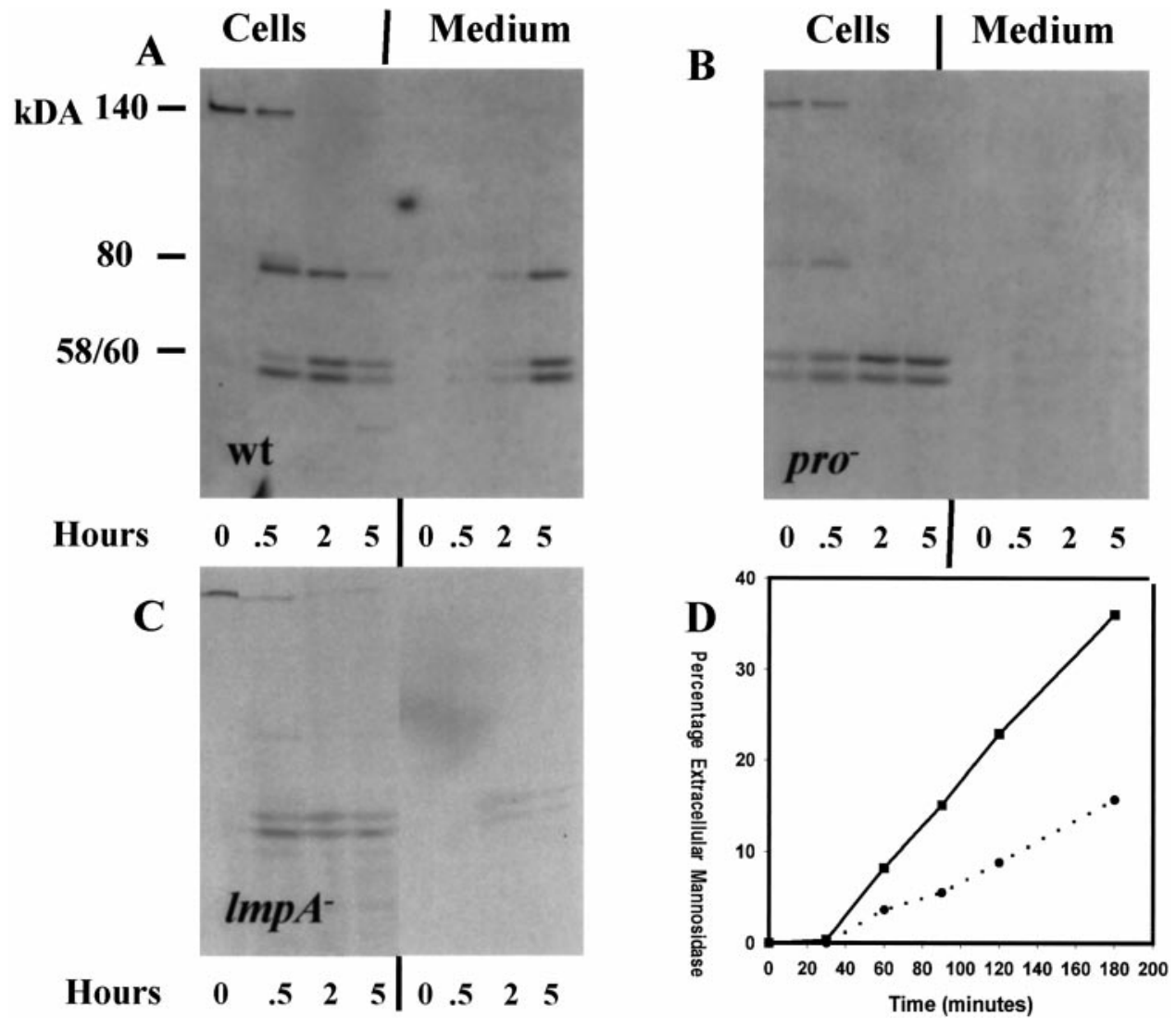

Figure 6. The targeting and processing of lysosomal enzymes are normal in $\operatorname{lmpA}$ and $\mathrm{pI} / \mathrm{II}^{-}$null cells; secretion of lysosomal $\alpha$-mannosidase is reduced in $\operatorname{lmp} A$ null cells. Wild-type, profilin-null, and LIMPnull strains growing in HL5 medium were pulse labeled with ${ }^{35}$ S]methionine for $20 \mathrm{~min}$ and chased in nonradioactive fresh medium. (A-C) At the times indicated, cells were harvested and $\alpha$-mannosidase was immunoprecipitated from cell lysates and supernatants and subjected to SDS-PAGE and fluorography. Cells in growth medium were also harvested by centrifugation and resuspended in fresh medium. (D) At the times indicated, samples were collected and the levels of $\alpha$-mannosidase activity were measured in wild-type

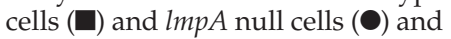
extracellular medium.
The deletion of the profilin genes results in an increase in phagocytosis and a decrease in macropinocytosis, supporting other studies indicating that these two processes are regulated by different signal transduction pathways in Dictyostelium. For instance, lack of PI 3-kinase activity (Buczynski et al., 1997b) and overexpression of RacC (Seastone et al., 1998) and Rap1 (Seastone et al., 1999), members of the Rho and Ras families of low-molecular-weight GTPases, respectively, result in the inhibition of macropinocytosis and the stimulation of phagocytosis. In addition, a deletion of the single gene encoding a $\beta$-subunit of the heterotrimeric $G$ protein results in the inhibition of phagocytosis (Peracino et al., 1998) but no change in pinocytosis (our unpublished results). Finally, the deletion of the $\operatorname{lmp} A$ gene results in defects in macropinocytosis but does not significantly affect phagocytosis. Other proteins, such as actin (Temesvari et al., 1996c; Jenne et al., 1998), coronin (Maniak et al., 1995; Rauchenberger et al., 1997), Rab7 (Buczynski et al., 1997a), and Scar (a Wasp-like protein; our unpublished results), appear to be required to regulate both processes. Figure 7 summarizes these findings in a schematic model that describes the roles of different proteins in the differential regulation of phagocytosis and macropinocytosis in Dictyostelium and the importance of $\mathrm{PIP}_{2}$ for regulation of both of these processes.

The studies described here also indicate that DdLIMP, a member of the CD36/LIMPII family of proteins, may functionally interact with profilin-regulated pathways to regulate membrane trafficking and actin cytoskeleton changes.
Earlier studies indicated that profilin and DdLIMP did not physically interact (Karakesisoglou et al., 1999). Some members of the LIMPII superfamily of proteins are thought to be lysosome-integral membrane proteins (Calvo et al., 1995). In fact, preliminary subcellular fractionation studies suggest that DdLIMP is enriched in lysosomes but not in postlysosomes in Dictyostelium (our unpublished results). We also report that DdLIMP is found in early endocytic vesicular structures (macropinosomes), and based on genetic suppression data, DdLIMP appears to act antagonistically to most of the processes regulated by profilin. Given the intracellular location of DdLIMP, it is not surprising that the secretion defect was not corrected in the profilin/DdLIMP triple null cell lines; secretion is thought to be a "late event" involving exocytosis of the contents of postlysosomes, and DdLIMP was found to localize in early endocytic compartments and perhaps lysosomes (Souza et al., 1997).

Based on the genetic suppression data and the intracellular location of DdLIMP to macropinosomes and perhaps lysosomes, it was not surprising that $\operatorname{lmp} A$ null mutants generated in a wild-type background were defective in endocytosis and endosomal membrane trafficking. Given the fact that $\operatorname{lmp} A$ inactivation reduced the high levels of F-actin in $\mathrm{pI} / \mathrm{II}$ null cells, we predicted that generation of $\operatorname{lmp} A$ null mutants in a wild-type background would lead to a reduction in F-actin levels relative to control cells. If true, this might account for the reduction in endocytosis and endosomal membrane trafficking in the $\operatorname{lm} p A$ null mutants, because F-actin is required for these processes. However, F-actin 
Figure 7. Macropinocytosis and phagocytosis are biochemically distinct processes. Phagocytosis and macropinocytosis are actindriven processes that both require Rab7, myosin I's, and coronin. Phosphatidylinositol 4,5-bisphosphate also appears to play an important role in both processes. The model proposes that PI 3-kinase generates PI $(3,4,5) \mathrm{P}_{3}$, which together with profilin and LIMP regulates macropinocytosis. The activity of PLC generates diacylglycerol (DAG) and inositide trisphosphate $\left(\mathrm{IP}_{3}\right)$ in combination with the GTPases Rap1 and RacC to regulate phagocytosis. In addition, published data support a negative role for Rap1 and $\mathrm{RacC}$ in macropinocytosis.

levels in $\operatorname{lmp} A$ null cells were not significantly different from the levels measured in wild-type cells. Members of the CD36 family have been implicated in the regulation of phagocytosis (Fadok et al., 1998); however, $\operatorname{lmp}$ A null cells were not significantly impaired in the internalization of latex beads.

What models can account for the fact that both profilin and DdLIMP bind PIP $_{2}$ (Goldschmidt-Clermont et al., 1990; Sohn et al., 1995; Lambrechts et al., 1997; Karakesisoglou et al., 1999) and yet appear, based on genetic suppression studies, to have opposing effects on macropinocytosis, phagocytosis, and fluid efflux? It is possible that DdLIMP competes with profilin by clustering PIP $_{2}$ in microdomains on endolysosomal membranes, preventing its interaction with profilin. Consistent with this possibility, profilin appears to localize to the cytoplasm and the cortex, where it is particularly enriched in macropinosomal cups (our unpublished data). Also, others have demonstrated that a significant percentage of total Dictyostelium endolysosomal lipids consists of $\mathrm{PIP}_{2}$ (Nolta et al., 1994). This local concentration of $\mathrm{PIP}_{2}$ could, in turn, recruit other cytosolic $\mathrm{PIP}_{2}$-binding proteins, which may be important in vesicle formation or consumption. In the absence of profilin, an increase in the clustering of PIP ${ }_{2}$ by DdLIMP could result in the abnormal recruitment of other $\mathrm{PIP}_{2}$-binding proteins involved in regulating vesicle movement, leading to aberrant trafficking. The removal of DdLIMP in the profilin-null background would abrogate the abnormal $\mathrm{PIP}_{2}$ clustering and protein recruitment and thus reverse the aberrant trafficking events. A second model proposes that profilin binds to $\mathrm{PIP}_{2}$ and recruits PI 3-kinases to the plasma membrane and internal membranes to generate $\mathrm{PIP}_{3}$, which in turn triggers the formation of macropinosomes and endosomal membrane flux. In the absence of profilin, PI 3-kinase would be less efficiently recruited to the plasma membrane and internal membranes, and macropinocytosis and efflux rates would decrease. The absence of DdLIMP in a profilin-minus background might increase the amount of $\mathrm{PIP}_{2}$ available and, by mass action, increase the rate of formation of $\mathrm{PIP}_{3}$ via PI 3-kinase recruitment. Finally, it is possible that the increased cortical actin observed in profilin-null cells blocks macropinocytosis, but as described above, it may stimulate phagocytosis. The inactivation of the $\operatorname{lmp} A$ gene in the profilin-null cells reduces the levels of cortical actin to wild-type levels, which may favor macropinocytosis and decrease phagocytosis to rates observed in wild-type cells.

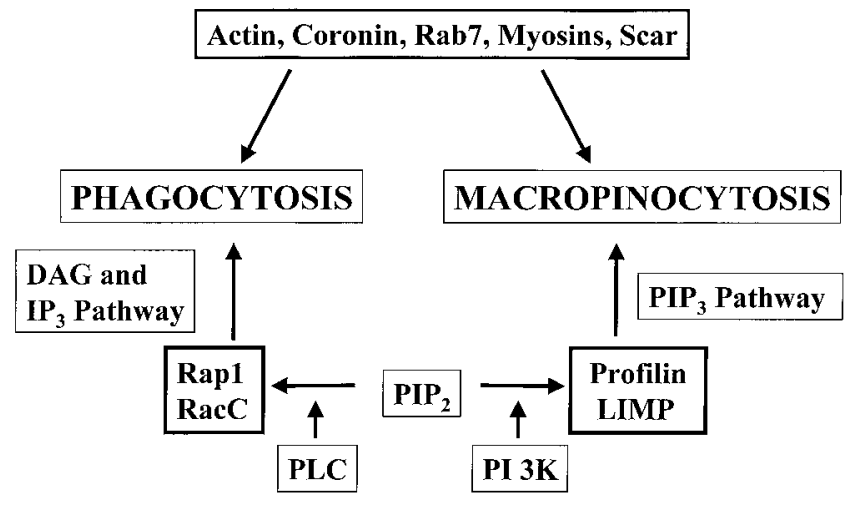

None of these models adequately explains how the absence of either one of two sets of genes results in defects in macropinocytosis but deletion of both sets results in strains that are normal in this process. This puzzling observation is not without precedent. Inactivation of the yeast gene encoding either profilin or a member of the arp $2 / 3$ complex results in misregulation of cortical actin patches, suggesting that both groups of proteins play a positive role in this process. However, combining both mutations results in strains that localize actin correctly to cortical patches (Balasubramanian et al., 1996).

In conclusion, this study demonstrates that profilin and DdLIMP are both important proteins regulating internalization and trafficking steps along the endosomal pathway and that these proteins may perform these roles through association with phosphoinositides and regulation of F-actin polymerization. To gain further insight into this hypothesis, current studies are directed toward measuring the level and defining the subcellular localization of phosphoinositides in $\operatorname{lm} p A$ null, $p I / I I$ null, and $\operatorname{lmp} A / p I / p I I$ null cell lines and determining the nature of the proteins that interact with profilin and DdLIMP.

\section{ACKNOWLEDGMENTS}

The authors thank Daniela Reiger for excellent technical assistance. The authors gratefully acknowledge the support of the Feist-Weiller Cancer Center. This work was supported by National Institutes of Health grant DK39232 to J.A.C. and by Deutsche Forschungsgemeinschaft grant SFB413 to M.S.

\section{REFERENCES}

Aubry, L., Klein, G., Martiel, J.-L., and Satre, M. (1993). Kinetics of endosomal $\mathrm{pH}$ evolution in Dictyostelium discoideum amoebae: study by fluorescence spectroscopy. J. Cell Sci. 105, 861-866.

Balasubramanian, M.K., Feoktistova, A., McCollum, D., and Gould, K.L. (1996). Fission yeast Sop2p: a novel and evolutionarily conserved protein that interacts with Arp3p and modulates profilin function. EMBO J. 15, 6426-6437.

Bhargavi, V., Chari, V.B., and Singh, S.S. (1998). Phosphatidylinositol 3-kinase binds to profilin through the p85 alpha subunit and regulates cytoskeletal assembly. Biochem. Mol. Biol. Int. 46, 241-248.

Buczynski, G., Bush, J., Zhang, L., Rodriguez-Paris, J., and Cardelli, J. (1997a). Evidence for a recycling role for Rab7 in regulating a late 
step in endocytosis and in retention of lysosomal enzymes in Dictyostelium discoideum. Mol. Biol. Cell 8, 1343-1360.

Buczynski, G., Grove, B., Nomura, A., Kleve, M., Bush, J., Firtel, R.A., and Cardelli, J. (1997b). Inactivation of two Dictyostelium discoideum genes, DdPIK1 and DdPIK2, encoding proteins related to mammalian phosphatidylinositide 3-kinases, results in defects in endocytosis, lysosome to postlysosome transport, and actin cytoskeleton organization. J. Cell Biol. 136, 1271-1286.

Bush, J., Temesvari, L., Rodriguez-Paris, J., Buczynski, G., and Cardelli, J. (1996). A role for a Rab4-like GTPase in endocytosis and in regulation of contractile vacuole structure and function in Dictyostelium discoideum. Mol. Biol. Cell 7, 1623-1628.

Calvo, D., Dopazo, J., and Vega, M.A. (1995). The CD36, CLA-1 (CD36L1), and LIMPII (CD36L2) gene family: cellular distribution, chromosomal location, and genetic evolution. Genomics 25, 100106.

Cardelli, J. (1993). Regulation of lysosomal trafficking and function during growth and development of Dictyostelium discoideum. In: Advances in Cell and Molecular Biology of Membranes, ed. Tartakoff, Storrie, and Murphy, Greenwich, CT: JAI Press, 341-390.

Cardelli, J.A., Richardson, J., and Miears, D. (1988). Role of acidic intracellular compartments in the biosynthesis of Dictyostelium lysosomal enzymes: the weak bases ammonium chloride and chloroquine differentially affect proteolytic processing and sorting. J. Biol. Chem. 264, 3454-3463.

Carlsson, L., Nystrom, L.E., Sundkvist, I., Markey, F., and Lindberg, U. (1977). Actin polymerizability is influenced by profilin, a low molecular weight protein in non-muscle cells. J. Mol. Biol. 115, $465-483$.

Cooley, L., Verheyen, E., and Ayers, K. (1992). chickadee encodes a profilin required for intercellular cytoplasm transport during Drosophila oogenesis. Cell 69, 173-184.

Fadok, V.A., Warner, M.L., Bratton, D.L., and Henson, P.M. (1998). CD36 is required for phagocytosis of apoptotic cells by human macrophages that use either a phosphatidylserine receptor or the vitronectin receptor (alpha v beta 3). J. Immunol. 161, 6250-6257.

Free, S.J., and Loomis, W.F. (1974). Isolation of mutations in Dictyostelium discoideum affecting alpha-mannosidase. Biochimie 56, 15251528 .

Goldschmidt-Clermont, P.J., Furman, M.I., Wachsstock, D., Safer, D., Nachmias, V.T., and Pollard, T.D. (1992). The control of actin nucleotide exchange by thymosin beta 4 and profilin: a potential regulatory mechanism for actin polymerization in cells. Mol. Biol. Cell 3, 1015-1024.

Goldschmidt-Clermont, P.J., Machesky, L.M., Baldassare, J.J., and Pollard, T.D. (1990). The actin-binding protein profilin binds to PIP 2 and inhibits its hydrolysis by phospholipase C. Science 247, 15751578

Haarer, B.K., Lillie, S.H., Adams, A.E.M., Magdolen, V., Bandlow, W., and Brown, S.S. (1990). Purification of profilin from Saccharomyces cerevisiae and analysis of profilin-deficient cells. J. Cell Biol. 110, 105-114.

Hacker, U., Albrecht, R., and Maniak, M. (1997). Fluid-phase uptake by macropinocytosis in Dictyostelium. J. Cell Sci. 110, 105-112.

Haugwitz, M., Noegel, A.A., Karakesisoglou, J., and Schleicher, M. (1994). Dictyostelium amoebae that lack G-actin-sequestering profilins show defects in F-actin content, cytokinesis, and development. Cell 79, 303-314.

Jenne, N., Rauchenberger, R., Hacker, U., Kast, T., and Maniak, M. (1998). Targeted gene disruption reveals a role for vacuolin B in the late endocytic pathway and exocytosis. J. Cell Sci. 111, 61-70.
Karakesisoglou, I., Janssen, K.P., Eichinger, L., Noegel, A.A., and Schleicher, M. (1999). Identification of a suppressor of the Dictyostelium profilin-minus phenotype as a CD36/LIMP-II homologue. J. Cell Biol. 145, 167-181.

Lambrechts, A., Verschelde, J.L., Jonckheere, V., Goethals, M., Vandekerckhove, J., and Ampe, C. (1997). The mammalian profilin isoforms display complementary affinities for PIP2 and proline-rich sequences. EMBO J. 16, 484-494.

Magdolen, V., Drubin, D.G., Mages, G., and Bandlow, W. (1993). High levels of profilin suppress the lethality caused by overproduction of actin in yeast cells. FEBS Lett. 316, 41-47.

Maniak, M., Rauchenberger, R., Albrecht, R., Murphy, J., and Gerisch, G. (1995). Coronin involved in phagocytosis: dynamics of particle-induced relocalization visualized by a green fluorescent protein tag. Cell 83, 915-924.

Mockrin, S.C., and Korn, E.D. (1980). Acanthamoeba profilin interacts with G-actin to increase the rate of exchange of actin-bound adenosine 5'-triphosphate. Biochemistry 19, 5359-5362.

Nolta, K.V., Rodriguez-Paris, J.M., and Steck, T.L. (1994). Analysis of successive endocytic compartments isolated from Dictyostelium discoideum by magnetic fractionation Biochim. Biophys. Acta 1224, 237-246.

O'Halloran, T.J., and Anderson, R.G.W. (1992). Clathrin heavy chain is required for pinocytosis, the presence of large vacuoles, and development in Dictyostelium. J. Cell Biol. 118, 1371-1377.

Padh, H., Lavassa, M., and Steck, T.L. (1993). A post-lysosomal compartment in Dictyostelium discoideum. J. Biol. Chem. 268, 67426747.

Pantaloni, D., and Carlier, M.F. (1993). How profilin promotes actin filament assembly in the presence of thymosin beta 4 . Cell 75, 1007-1014.

Peracino, B., Borleis, J., Jin, T., Westphal, M., Schwartz, J.M., Wu, L., Bracco, E., Gerisch, G., Devreotes, P., and Bozzaro, S. (1998). G protein beta subunit-null mutants are impaired in phagocytosis and chemotaxis due to inappropriate regulation of the actin cytoskeleton. J. Cell Biol. 141, 1529-1537.

Rauchenberger, R., Hacker, U., Murphy, J., Niewohner, J., and Maniak, M. (1997). Coronin and vacuolin identify consecutive stages of a late, actin-coated endocytic compartment in Dictyostelium. Curr. Biol. 7, 215-218.

Rodriguez-Paris, J.M., Nolta, K.V., and Steck, T.L. (1993). Characterization of lysosomes isolated from Dictyostelium discoideum by magnetic fractionation. J. Biol. Chem. 268, 9110-9116.

Rupper, A., Rodriguez-Paris, J., Grove, B., and Cardelli, J. (1998). p110-related PI 3-kinases regulate phagosome-phagosome fusion and phagosomal pH in Dictyostelium. Mol. Biol. Cell 9, 463a.

Ruscetti, T., Cardelli, J.A., Niswonger, M.L., and O'Halloran, T.J. (1994). Clathrin heavy chain functions in sorting and secretion of lysosomal enzymes in Dictyostelium discoideum. J. Cell Sci. 126, 343352.

Seastone, D.J., Lee, E., Bush, J., Knecht, D., and Cardelli, J. (1998). Overexpression of a novel rho family GTPase, RacC, induces unusual actin-based structures and positively affects phagocytosis in Dictyostelium discoideum. Mol. Biol. Cell 9, 2891-2904.

Seastone, D.J., Zhang, L., Buczynski, G., Rebstein, P., Weeks, G., Spiegelman, G., and Cardelli, J. (1999). The small $\mathrm{M}_{\mathrm{r}}$ Ras-like GTPase Rap1 and the phospholipase $\mathrm{C}$ pathway act to regulate phagocytosis in Dictyostelium discoideum. Mol. Biol. Cell 10, 393-406.

Shariff, A., and Luna, E.J. (1992). Diacylglycerol-stimulated formation of actin nucleation sites at plasma membranes. Science 256, 245-247. 
Singh, S.S., Chauhan, A., Murakami, N., and Chauhan, V.P. (1996). Localization of a binding site for phosphatidylinositol 4,5-bisphosphate on human profilin. Biochemistry 35, 16544-16549.

Sohn, R.H., Chen, J., Koblan, K.S., Bray, P.F., and GoldschmidtClermont,P.J.(1995).Localization ofabindingsiteforphosphatidylinositol 4,5-bisphosphate on human profilin. J. Biol. Chem. 270, 2111421120.

Souza, G.M., Mehta, D.P., Lammertz, M., Rodriguez-Paris, J., Wu, R., Cardelli, J.A., and Freeze, H.H. (1997). Dictyostelium lysosomal proteins with different sugar modifications sort to functionally distinct compartments. J. Cell Sci. 110, 2239-2248.

Temesvari, L., Bush, J., Peterson, M., Novak, K., Titus, M., and Cardelli, J. (1996a). Examination of the endosomal and lysosomal pathways in Dictyostelium discoideum myosin I mutants. J. Cell Sci. 109, 663-673.

Temesvari, L., Rodriguez-Paris, J., Bush, J., Steck, T.L., and Cardelli, J. (1994). Characterization of lysosomal membrane proteins of Dictyostelium discoideum: a complex population of acidic integral membrane glycoproteins, Rab GTP-binding proteins and vacuolar ATPase subunits. J. Biol. Chem. 269, 25719-25727.
Temesvari, L.A., Bush, J., Peterson, M., Titus, M., and Cardelli, J. (1996b). Involvement of the vacuolar proton-translocating ATPase in multiple steps of the endo-lysosomal system and in the contractile vacuole system of Dictyostelium discoideum. J. Cell Sci. 109, 14791495.

Temesvari, L.A., Zhang, L., and Cardelli, J.A. (1996c). The role of the actin cytoskeleton in endo-lysosomal system of Dictyostelium discoideum. Mol. Biol. Cell 7, 451a.

Vinson, V.K., De La Cruz, E.M., Higgs, H.N., and Pollard, T.D. (1998). Interactions of Acanthamoeba profilin with actin and nucleotides bound to actin. Biochemistry 37, 10871-10880.

Whitney, J.A., Gomez, M., Sheff, D., Kreis, T.E., and Mellman, I. (1995). Cytoplasmic coat proteins involved in endosome function. Cell 83, 703-713.

Witke, W., Podtelejnikov, A.V., Di Nardo, A., Sutherland, J.D., Gurniak, C.B., Dotti, C., and Mann, M. (1998). In mouse brain profilin I and profilin II associate with regulators of the endocytic pathway and actin assembly. EMBO J. 17, 967-976. 